\title{
Neighbourhood facilities for sustainability
}

\author{
J. Gibberd \\ CSIR, Department of Architecture, University of Pretoria, South Africa
}

\begin{abstract}
It is increasingly acknowledged that current plans to implement sustainability are not achieving the scale and speed of change required. National built environment strategies to address sustainability tend to focus on large-scale programmes in areas such as renewable energy and energy efficiency. While this approach can improve national environmental indicators such as carbon emissions profiles; it appears unlikely to achieve sustainability.

This paper argues that more comprehensive, and more local, approaches are required. Interventions at a neighbourhood level should be developed that enable day-to-day living patterns to become more sustainable over time. A key element of this are built environment characteristics and facilities which support sustainability. In this paper these are referred to as 'Neighbourhood Facilities for Sustainability'.

Neighbourhood Facilities for Sustainability (NFS) are initiatives undertaken by individuals and communities to build local sustainable systems which not only improve their quality of life but also reduce environmental impacts. The paper argues that this approach is a valuable way of ensuring that sustainability is addressed rapidly and effectively in urban settings. It also argues that the NFS approach may be more efficient and effective than national programmes as it responds to the local context and develops local ownership and capacity to which ensures systems are well managed and maintained. The approach will be illustrated through NFS proposals developed for an informal settlement neighbourhood in South Africa. These proposals will be critically reviewed and recommendations for further study, made.
\end{abstract}

Keywords: facilities, neighbourhood, streets, sustainability. 


\section{Introduction}

National policy and plans for the built environment may choose to address sustainability through national programmes on energy efficiency and renewable energy [1-3]. While the approach may affect national carbon emissions profiles, key social, economic and environmental problems and unsustainable patterns of day-to-day living remain. In addition, renewable energy and energy efficiency interventions based on expensive foreign technology divert scarce resources from programmes that could address environmental, social and economic problems such as pollution, poor education, ill-health and unemployment.

This paper argues that energy efficiency and renewable energy systems must be one strand of a more comprehensive strategy to implement sustainability. It proposes an alternative approach to implementing sustainability which focuses on the concept of Neighbourhood Facilities for Sustainability. These local facilities aim to enable households and communities to improve their quality of living in ways that also reduce environment impacts and carbon emissions. In particular, these facilities and the associated technology aim to influence day-today living patterns and behaviours to support sustainability. The approach therefore aims to ensure that both technical and behavioural sustainability, as defined by Williams [4], exists.

In order to develop the concept of Neighbourhood Facilities for Sustainability, sustainability definitions are analysed from first principles to understand the key implications of the concept for the built environment. These implications are extrapolated to describe neighbourhood facilities that could be created to support, and enable, sustainability. The paper critically reviews the concept of Neighbourhood Facilities for Sustainability and makes recommendations for further research.

\section{Defining sustainability}

There are a wide variety of definitions for sustainability. While many of these are vague and therefore difficult to implement, others include quantitative targets that can be aimed for [5]. A definition of sustainability that is particularly relevant to the built environment has been developed by the World Wildlife Fund.

This describes sustainability in human communities as the achievement of above 0.8 on the Human Development Index (HDI) and the achievement of an Ecological Footprint (EF) below 1.8 global hectares per person [6]. In this paper this is referred to as the EF-HDI definition.

\subsection{Human Development Index}

The United Nations developed the Human Development Index as a quality of life measure [7]. The measure is based on:

- $\quad$ A long healthy life, measured by life expectancy at birth; 
- $\quad$ Knowledge, measured by the adult literacy rate and combined primary, secondary, and tertiary gross enrolment ratio;

A decent standard of living, as measure by the GDP per capital in purchasing power parity (PPP) in terms of US dollars.

The Index is established by measuring performance between minimum and maximum values (goalposts) for a number of indicators. These goalposts are outlined below:

\section{Dimensional indicator}

Life expectancy at birth

Adult literacy rate (\%)

Combined gross enrolment ratio (\%)

GDP per capita (PPP US\$)

\section{Maximum value}

85

100

100

40,000
Minimum value

25

0

0

100

The Human Development Index is the average of three dimensional indexes:

$\mathrm{HDI}=1 / 3$ (life expectancy index) $+1 / 3$ (education index) $+1 / 3$ (GDP index)

An Ecological Footprint is the amount of biologically productive land and sea required to provide the resources a human population consumes, as well as the resource required to absorb corresponding waste. It is based on consumption of resources and production of waste and emissions in the following areas:

- $\quad$ Food, measured in type and amount of food consumed

- $\quad$ Shelter, measured in size, utilization and energy consumption

- Mobility, measured in type of transport used and distances travelled

- $\quad$ Goods, measured in type and quantity consumed

- $\quad$ Services, measured in type and quantity consumed

- $\quad$ Waste, measured in type and quantity produced

The area of biologically productive land and sea for each of these areas is calculated in global hectares (gha) and then added together to provide an overall ecological footprint [8]. This measure is particularly useful as it enables the impact of infrastructure and lifestyles to be measured in relation to the earth's carrying capacity of 1.8 global hectares (gha) per person.

\section{Neighbourhood Facilities for Sustainability (NFS)}

Neighbourhood Facilities for Sustainability can be derived from this definition of sustainability by ascertaining the built environment characteristics for each of the EF-HDI sustainability criteria such as Food, Mobility etc. These in turn, can be used to propose neighbourhood facilities that would embody these characteristics. This is illustrated in table 1. 
Table 1: $\quad$ Neighbourhood facilities for sustainability.

\begin{tabular}{|c|c|c|}
\hline $\begin{array}{l}\text { Sustainability } \\
\text { criteria }\end{array}$ & $\begin{array}{l}\text { Sustainable built } \\
\text { environment } \\
\text { characteristics } \\
\end{array}$ & $\begin{array}{l}\text { Neighbourhood facilities for } \\
\text { sustainability }\end{array}$ \\
\hline Food & $\begin{array}{l}\text { Local markets with } \\
\text { low ecological } \\
\text { footprint foods. } \\
\text { Ability to produce low } \\
\text { ecological footprint } \\
\text { food. }\end{array}$ & $\begin{array}{l}\text { Vegetable gardens and fruit } \\
\text { orchards } \\
\text { Rainwater harvesting, water } \\
\text { storage and irrigation scheme } \\
\text { Soil fertility measures including } \\
\text { composting } \\
\text { Neighbourhood food markets }\end{array}$ \\
\hline Shelter & $\begin{array}{l}\text { Appropriately sized, } \\
\text { resource efficient } \\
\text { accommodation. }\end{array}$ & $\begin{array}{l}\text { Local renewable energy systems } \\
\text { Local solar water heating } \\
\text { systems } \\
\text { Local accommodation rental pool } \\
\text { Building performance upgrading } \\
\text { including access to local skills } \\
\text { and bulk building material } \\
\text { purchasing }\end{array}$ \\
\hline Mobility & $\begin{array}{l}\text { Daily requirements } \\
\text { accessible within } \\
\text { walking distance. } \\
\text { Access to local public } \\
\text { transport. }\end{array}$ & $\begin{array}{l}\text { Local non-motorised } \\
\text { transportation systems } \\
\text { Local bicycle hire and repairs } \\
\text { Pedestrian and cycle network of } \\
\text { safe, easy-to-use routes }\end{array}$ \\
\hline Goods & $\begin{array}{l}\text { Appropriate goods } \\
\text { available locally. } \\
\text { Facilities to support } \\
\text { efficient usage/shared } \\
\text { use of goods. }\end{array}$ & $\begin{array}{l}\text { Local equipment hire /share } \\
\text { scheme } \\
\text { Bulk purchasing schemes }\end{array}$ \\
\hline Services & $\begin{array}{l}\text { Appropriate services } \\
\text { available locally. } \\
\text { Facilities to support } \\
\text { efficient usage of } \\
\text { services. }\end{array}$ & $\begin{array}{l}\text { Local affordable business centre } \\
\text { with access to knowledgeable } \\
\text { personnel, computers, internet, } \\
\text { printing and photocopying }\end{array}$ \\
\hline Health & $\begin{array}{l}\text { Access to sports, } \\
\text { health, leisure } \\
\text { facilities. } \\
\text { Access to healthy food } \\
\text { and clean water. } \\
\text { No local hazards such } \\
\text { as violent crime and } \\
\text { pollution. }\end{array}$ & $\begin{array}{l}\text { Access to cooking and heating } \\
\text { systems which do not affect air } \\
\text { quality and health } \\
\text { Sports and recreation facilities } \\
\text { such as volleyball courts and } \\
\text { play equipment } \\
\text { Local provision of clean water } \\
\text { such as shared rainwater } \\
\text { harvesting scheme } \\
\text { Local access to affordable } \\
\text { healthy food. }\end{array}$ \\
\hline
\end{tabular}


Table 1: $\quad$ Continued.

\begin{tabular}{|l|l|l|}
\hline $\begin{array}{l}\text { Sustainability } \\
\text { criteria }\end{array}$ & $\begin{array}{l}\text { Sustainable built } \\
\text { environment } \\
\text { characteristics }\end{array}$ & $\begin{array}{l}\text { Neighbourhood facilities for } \\
\text { sustainability }\end{array}$ \\
\hline Knowledge & $\begin{array}{l}\text { Access to primary, } \\
\text { secondary, tertiary and } \\
\text { on-going learning } \\
\text { facilities. }\end{array}$ & $\begin{array}{l}\text { Local access to low/no cost } \\
\text { internet. } \\
\text { Local crèche } \\
\text { Local homework/study facility } \\
\text { Transportation/walking/cycling } \\
\text { support for learners accessing } \\
\text { education outside the area }\end{array}$ \\
\hline $\begin{array}{l}\text { Standard of } \\
\text { living }\end{array}$ & $\begin{array}{l}\text { Access to employment } \\
\text { opportunities. } \\
\text { Self-employment } \\
\text { opportunities. } \\
\text { Access to support for } \\
\text { small enterprise } \\
\text { development. }\end{array}$ & $\begin{array}{l}\text { Local retailers for food and } \\
\text { goods } \\
\text { Local maintenance, food } \\
\text { production, recycling, transport, } \\
\text { energy, education enterprises } \\
\text { Low cost/free access to internet } \\
\text { and telephone communication. }\end{array}$ \\
\hline
\end{tabular}

This process has also been used to develop a tool for assessing sustainability in neighbourhoods termed the Built Environment Sustainability Tool (BEST) [9].

\section{Neighbour case study}

The neighbourhood selected to apply the concept of Neighbourhood Facilities for Sustainability is an area of Atteridgeville, a suburb of Pretoria in South Africa (latitude -25.7733, longitude 28.0713). As illustrated in figure 1, housing consists of self-built informal dwellings organised within in a loosely planned grid. The local municipality has not been able to keep up with the growth of these settlements and service infrastructure is basic and consists of a water supply (brought in by tankers) and some graded roads. Street lighting, storm water drainage, piped water, electricity, parks, schools, and conventional health, sports, leisure and retail facilities do not exist within the neighbourhood.

There are however small 'spazas' (stalls) that sell some essential groceries, areas of 'scraped ground' which are used for football matches, local taxis that can be hired to transport goods and people, local recyclers that gather paper, metal and plastic waste and some small household vegetable gardens. Wilson [10] and Baud [11] note that these informal systems have many advantages in terms of sustainability and this is reflected in the type of facilities proposed later in the paper. The neighbourhood is typical of many rapidly developing informal settlements in Africa. 


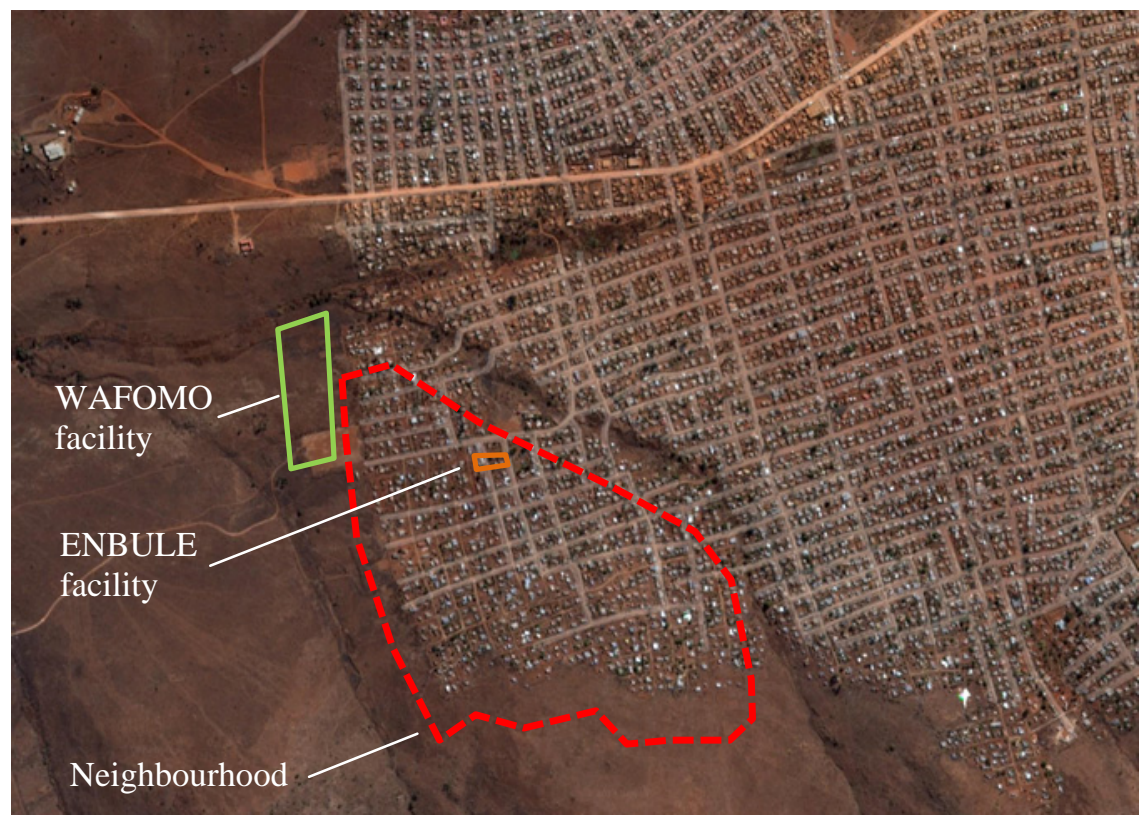

Figure 1: $\quad$ Area with indicative neighbourhood facilities for sustainability.

\section{Discussion}

While a number of facilities that may support local sustainability can identified, many questions remain. What infrastructure will be required to establish these facilities? Where would the capital for these facilities come from? Who would own these facilities and how would they be run? These are complex questions that are not easily answered. However some ideas can be explored.

An efficient way of establishing these facilities is to cluster and combine as many compatible functions together so that capital and operation costs can be shared and therefore reduced. This results in two main facilities; a water, food and mobility facility and energy, business and learning facility.

\subsection{Water, Food and Mobility Facility (WAFOMO)}

A food, water mobility facility would be located near the lowest point of the neighbourhood where rainwater could be drained to and stored. This would be used to irrigate vegetable and fruit gardens (indicated as 'WAFOMO' on figure 1) An allotment arrangement for gardens could be used to there was equitable access to these gardens by households within the neighbourhood and that costs of maintenance and irrigation could be shared to make this affordable. A food market could be located adjacent to these gardens where produce, as well as other food, could be sold. Finally, a system of non-motorised transport could be used to transport excess produce to other markets and bring back food and 
goods from other areas to the neighbourhood. This would enable low cost transportation, create local employment and avoid ever-increasing costs and emissions associated with motorised transport.

Capital costs for the WAFAMO facility could be minimised by drawing on community labour. For instance, excavating rainwater tanks and allotment plot preparation could be carried out by hand. On-going costs would be covered by an annual allotment plot rental fee which would be collected and administered by an elected committee. A small fee would be levied on the transportation of goods to pay porters.

\subsection{Energy, Business and Learning Facility (ENBULE)}

Initially the business, energy and learning facility could consist of a single classroom-type space (indicated as 'ENBULE' in figure 1). This would have computers and reprographic equipment on one side and a working area with tables and chairs on the other. The facility would be tightly scheduled and open for long hours to ensure that all members of the neighbourhood were able to access this if they wanted to. Computers and reprographics would be available to support local business and e-commerce as well adult and children learners. The primary purpose for the working area would be for classes and for children to do homework. This facility would thus enable small businesses and learners to access information and data from the internet and have a lit, comfortable space for working which may not available at home. Energy could be generated through a photovoltaic system on the roof which would power lighting and computers. This energy could also be used to charge small appliances such as mobile phone, radios and lights, to enable non-electrified households to use these at home.

The capital cost of the ENBULE facility is likely to be substantial and this could be raised in a range of ways. One way would be for members of the neighbourhood to form an association and raise funding with annual fees and fund raising events. Another way would be to structure a long term agreement with a company to develop and run this facility. The agreement would require the private company to provide access at low cost to this facility for the majority of the time while allowing the company to provide additional services, such as such as classes and reprographic services, where profit could be generated. In South Africa substantial funding is available for classes and training from Sector Education Training Authorities (SETAs) and this could be drawn on to enhance the financial viability of the project for a private investor. On-going costs of the facility could be made be made sustainable and affordable through monthly membership fees for access to the facility. With enough members and long operational hours, the facility could be well used and monthly costs could be kept low.

The Neighbourhood Facilities for Sustainability model is attractive as it enables communities to improve education, employment and health levels as well as local social cohesion and proactively build local sustainability without having to rely on external parties such as government and NGOs [12, 13]. Increased social capital has a range of benefits including reduced transactional 
costs and increased sharing and trust $[14,15]$. It also serves to reduce the negative impacts associated with social exclusion such as underachievement in education and the job market, low incomes, ill-health and crime [16].

NFS facilities also have relatively low capital and operational costs which should make them affordable for communities, particularly, as some members would be employed and others are able to access grants and pensions provided by the government. The key advantage of the model is that any income received by the community can be effectively recycled within the community by ensuring that most day-to-day requirements such as food, energy, water, mobility and learning are provided locally [17].

The facilities however rely heavily on effective organisational structures which are able to mobilise and engage community members in developing and running these facilities. This may be problematic where households are highly fragmented and transient. In addition, the type of infrastructure required for these facilities includes buildings, water tanks and gardens, which may require planning permission from a local authority. This can be complex process and for many communities, assistance and partnerships will be required [18].

It is important to note that the creation of these facilities may not necessarily mean that they will be supported, or change local behaviours [4]. The likelihood of this however may be reduced by the requirement within this model for communities to develop the facilities themselves rather than for these to be provided by external parties such as government. The complexity of community interaction and individual behaviour in relation to collective action problems (CAPs) however must be acknowledged [19].

\section{Conclusion and recommendations}

An exploration of how sustainability can be developed at local neighbourhood level provides interesting and useful results. The concept of Neighbourhood Facilities for Sustainability appears to offer a way that communities can proactively begin to address local sustainability without relying on government programmes. The concept is particularly attractive as it ensures that local living standards and, in particular, levels of education, health and income, can be improved ways without significant environmental impacts.

It is recommended that further research be carried out in the Neighbourhood Facility for Sustainability model in order to develop processes that can be piloted with communities. Monitoring of these pilots would determine the extent to which neighbourhood facilities affected local behaviour and improved sustainability performance. Further research in this area is necessary, as government will not be able create the scale and type of change required by themselves, and communities need to actively develop their own sustainable systems at a local level. 


\section{References}

[1] Barker, T., Climate Change 2007: An Assessment of the Intergovernmental Panel on Climate Change. Change, (November), pp. 12-17, 2007.

[2] United Nations, The Emissions Gap Report. November 2010. United Nations Environment Programme, 2010.

[3] Winkler, H., Long Term Mitigation Scenarios: Technical Report, Prepared by the Energy Research Centre for Department of Environment Affairs and Tourism, Pretoria, 2007.

[4] Williams, A., Framework of Sustainable Behaviours that can be Enabled through the Design of Neighbourhood-Scale Developments, Sustainable Development, Sust. Dev. 15, pp.160-173, 2007.

[5] Button, K., City management and urban environmental indicators. Ecological Economics, 40(2), pp. 217-233, 2002.

[6] World Wild Life Fund, The Living Planet Report, Accessed from www.panda.org/news_facts/publications/living_planet_report/linving_plan et_report_timeline/index.cfm, 2006.

[7] United Nations Development Programme, Human Development Report 2007/2008. United Nations Development Programme, New York, 2007.

[8] Wackernagel, M. and Yount, D., Footprints for Sustainability: the Next Steps, Environment, Development and Sustainability 2, Kluwer Academic Publishers, pp. 21-42, 2000.

[9] Gibberd, J., Sustainable African Built Environments, African Journal of Science, Technology, Innovation and Development, 2013.

[10] Wilson, D., Velis, C., \& Cheeseman, C., Role of informal sector recycling in waste management in developing countries, Habitat International 30, pp. 797-808. 2006.

[11] Baud, I., Grafakos, S., Hordijk, M. \& Post, J., Quality of Life and Alliances in Solid Waste Management Contributions to Urban Sustainable Development Cities, Vol. 18, No. 1, pp. 3-12, 2001.

[12] Pretty, J. \& Ward, H., 2001, Social capital and the environment, World Development, 29, pp. 209-227.

[13] Newman, L., The Virtuous Cycle: Incremental Changes and a ProcessBased Sustainable Development, Sustainable Development, Sust. Dev. 15, pp. 267-274, 2007.

[14] Fukuyama, F., Trust: the social virtues and the creation of prosperity, New York, Free Press, 1995.

[15] Putnam, R., Making Democracy Work, Princeton, NJ, Princeton University Press, 1993.

[16] Social Exclusion Unit, Preventing Social Exclusion: a Report by the Social Exclusion Unit. Cabinet Office: London, 2001.

[17] Dixon, T., \& Marston, A., Mixed Use Urban Regeneration at Brindley Place, Birmingham and Gunwharf Quays, Portsmouth: an Assessment of the Impact on Local and National Economies, research report for British Property Federation. College of Estate Management: Reading, 2003. 
234 The Sustainable City VIII, Vol. 1

[18] Cuthill, M., Exploratory research: citizen participation, local government and sustainable development in Australia, Sustainable Development 10, pp. 79-89, 2002.

[19] Rydin, Y., \& Holman, N., Re-evaluating the Contribution of Social Capital in Achieving Sustainable Development, The International Journal of Justice and Sustainability, 9:2, pp. 117-133, 2004. 